City University of New York (CUNY) CUNY Academic Works

2018

\title{
Who Are the Stewards of the AIDS Archive?
}

Alexandra Juhasz

CUNY Brooklyn College

Theodore Kerr

The New School

\section{How does access to this work benefit you? Let us know!}

More information about this work at: https://academicworks.cuny.edu/bc_pubs/201

Discover additional works at: https://academicworks.cuny.edu

This work is made publicly available by the City University of New York (CUNY).

Contact: AcademicWorks@cuny.edu 


\section{WHO ARE THE STEWARDS OF THE AIDS ARCHIVE?}

\author{
Sharing the political weight of the intimate
}

Alexandra Juhasz and Theodore (Ted) Kerr

Within these conversations Juhasz and Kerr have laid out a timeline of AIDS cultural production. Until President Ronald Reagan said AIDS in 1987, there was a prevailing silence around the then emerging epidemic from the government and media. People living with HIV and their communities were forced to be heard through aligned tactics of activism and media-making, expressing their commitment to saving each other's lives and demanding action and recognition from the too-quiet government and general public. Activists' use of video as a tool led to a powerful era of diverse, polyphonous, spirited media output. From 1987 to 1996 there was a cultural blossoming of street art, video work, theater, dance, literature, and visual art that spoke truth to power, as well as to pain, suffering, beauty, and hope. For example, in this period the red ribbon, Silence $=$ Death, and much more were created. This vivid cacophony was followed by what Kerr calls the Second Silence: ten or more years of reduced AIDS-related cultural expression following the release of life-saving HAART (Highly Affective Antiretroviral Treatment) in 1996. While the space AIDS took up in public discourse was reduced, there were ever more diagnoses, under-reported medical breakthroughs, policy changes, and ongoing death and suffering. Within the Second Silence there was also a reduction in the flow of AIDS-related media and communication. Thus, there was also a loss of information-sharing about the virus. To get and share information it was necessary to be already imbedded in the conversation. A gulf began to form between those who knew a lot and those who knew very little. Following the Second Silence came the AIDS Crisis Revisitation. Starting around 2008 a new era of increased AIDS visibility returned to the public realm defined by a surprising and exciting deluge of documentaries, feature films, books, and other forms of cultural production all exploring early responses to HIV/AIDS. However, all this attention was primarily focused on one slice-critical but isolated as the primary focus of attention - of AIDS history, expression, and experience.

In October 2016 Juhasz and Kerr performed a conversation at the CLAGS conference After Marriage to think through their timeline and consider the limits of what was coming out of the AIDS Crisis Revisitation. Their conversation was a proactive investigation: how do we move forward, look back, and make sense of what we are seeing in current representations of HIV/AIOS? How do representations make some histories and current realities more visible, while making others less visible? To respond to these questions, Juhasz and Kerr drew largely upon earlier video activist work of women, people of color, poor people, and others who have long practiced, saved, and shared their activism and media on the margins. Much of this work has not yet been represented within the AIDS Crisis Revisitation, but is available within Juhasz' AIDS personal and professional video archive.

One of the key insights that they shared in the After Marriage conversation, and continue in the text below, is that AIDS is often treated as a disruption in the fight for gay rights, which is now often tucked into the longer story of the march towards lesbian and gay equality. What Juhasz, Kerr, and others (such as Jih-Fei Cheng in his 2016 essay "How to Survive: AIDS and Its Afterlives in Popular Media" and Tyrone Palmer in his 2015 essay "Under the Rainbow") take issue 
with in the current foci of AIDS history is how it disappears the previous tradition that led to and fed AIDS activism, including an intersectional approach needed to understand that, as much as the epidemic is about (homo) sexuality, it is also about gender, race, class, geography, and much more.

Narrowing the discourse of AIDS history is similar to erecting hurdles when it comes to the unfinished queer agenda. In both cases, marriage acts both as a distraction and also a "win" with questionable impacts; meanwhile, the burdens and contribuand other disenfranchised communities are ignored, minitions of people of color and other disenfranchised communities are ignored, minimized, and not pulled forward. Juhasz and Kerr argue that uncovering and sharing the many ongoing and intersecting histories of the epidemic sheds light on norms that limit the current response to HIV/AIDS and may be hindering related activism, while providing possible, more generous roadmaps forward. Juhasz and Kerr begin by looking at the glaring white light that marriage equality cast over AIDS activism, and how the AIDS Crisis Revisitation continues to bleach out the multiplicity of strategies and communities long at the core of the AIDS response; the limits of strategies and communites long at the core of the AI addressing diversity, when structures of remembering and representation are embedded in white supremacy, are explored. At the core of Juhasz and Kerr's conversation is a rectamation of rarely shared AIDS histories and media that focus on the impact the virus has had on multiple communities from the beginning, and how an intersectional response to the crisis is as old as the crisis itself. By increasing the scope of AIDS tion le epidemic becomes less about history, the work to eliminate suffering related to the epidemic becomes less about reducing the transmission of the virus per se and molic lives.

\section{Part 1}

\section{Spelling it out: gay marriage and what gets lost}

THEODORE (TED) KERR: A good place to start this conversation is a 2015 short film by artist Hayat Hyatt entitled Villanelle. As described by Hyatt (2015) on his Vimeo page, the film is a blending of "documentary, poetry, and found footage" that "delves into the history of the AIDS crisis and its impact on gay black men living in New York City."

The central images of his film are black bodies, the ocean, and doubling: torsos and faces meeting/not-meeting the mirror images of themselves against the backdrop of a beach. This is spliced with an archival shot of a black child standing in school, cropped off from other students. Playing over the images are audio interviews between Hyatt and other black gay and queer men, their voices lapping over and on top of each other, creating waves of understanding voices lapping over and on top of each other, connection. The film begins with the consideration of how the release of life-prolonging AIDS medications in the mid to late 1990 s created a dividing line between the living and tions in the mid to late 1990 s created a dividing line between the live medication, as well as between those who lived through the early mass death years and those who did not.
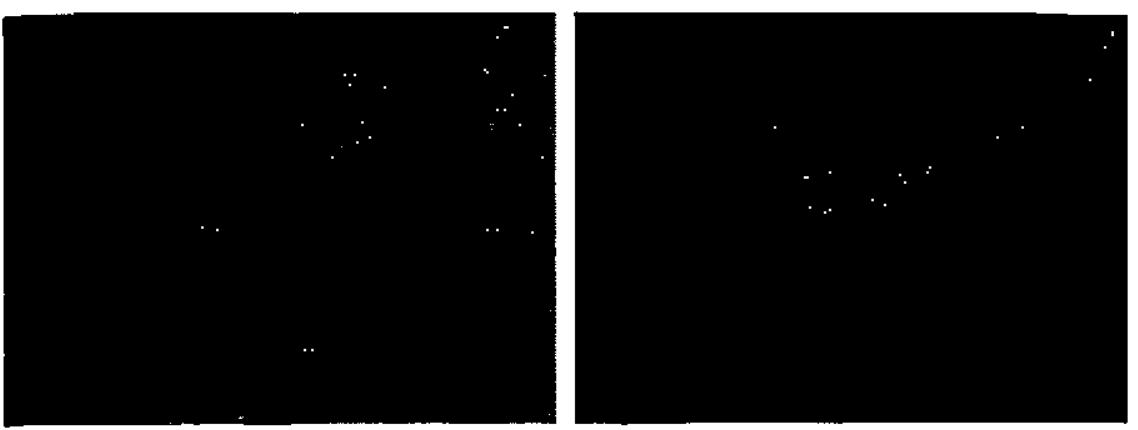

FIGURE 7.1 Villanelle (2015, dir. Hayat Hyatt)

As a voice in the film suggests, for those who lived through the earliest years of the AIDS crisis there was a sense that younger people would not understand what they had been through - so they kept it to themselves. As the film progresses other voices are heard considering how black gay men have been separated, the ways they try to connect, and the degrees to which they succeed in connecting. Within these stories they reconcile the forces they live within, including the specter of AIDS.

ALEXANDRA JUHASZ: For Hayat Hyatt, layering of sound and image provides for a multi-temporal and many-personed register that bridges past stories of black gay male loss and love with contemporary experience in a way that daily life and most media representations cannot provide, given the death of a generation of men and racism that has contributed to their stories not being saved. A voice says: "it was easier to see the story on the body of a white gay man than on an African, but meanwhile it's ravaging all these other communities...."

rK: Hyatt started interviewing black queer and gay men about their lives, and as he was doing so began to better understand the impact that HIV/AIDS had and was having on his peers. "These conversations," Hyatt shared with me over email, "provided me with a history I didn't know WE had." He learned that "the AIDS crisis is an ongoing issue. It didn't end with the advent of protease inhibitors in the 1990s and it's very much an issue for black and brown people around the world," and that "black communities are disproportionately impacted by the AIDS crisis because of lingering social inequities and stigma." He remembers hearing a news report suggesting that there had been no organized activism from black gay communities with the AIDS response. "Not only is this a lie," he came to learn, "but it erases all the work of black gay groups like GMAD and the many others that formed around the country, in response to the AIDS crisis" (H. Hyatt, personal communication, April 17, 2017).

In watching Villanelle I thought about a short film from your AIDS video archive, Mildred Pearson: When you Love a Person (Durand, 1988). The film begins with photographic images of a cute baby, moves on to pictures of a precocious boy, followed by those of a handsome man, and then we are met with 
snapshots of that man, still young, but towards the end of his life. As the accumulated images flip past, the man's mother, Mildred Pearson, narrates, tracking Bruce, her son's, life, whose end came too soon and with much pain as a result of AIDS and related physical and mental health problems. A production of the Brooklyn AIDS Task Force (BATF), Durand's Mildred Pearson: When you Love a Person is about loss and mourning. In the film Pearson laments the life and death of her son. The video is also a "trigger tape," a term I learned from you, which means that it was meant to be shown in group settings and followed up by a conversation triggered by the film. As per our stated goals, it is funny to think about the different charges of one word's meaning across generations. The word trigger, now used to denote a warning, was once an invitation.

AJ: The words "trigger film" are so common to me that I never made the connection to today's usage until this interaction! It wouldn't have dawned on me, especially given your work in the community, that you wouldn't be familiar with that term and its related interpersonal and pedagogic processes. This is an example of how known-knowns to one, but not another, can be a real obstacle to cross-generational engagements.

But, yes, activist video was being made with a fundamental understanding that it would be viewed with others, in community, as a form of education, activism, and shared local empowerment. I engaged video activist Catherine Saalfield (now Gund), to write a special videography for $A I D S T V$ that would explain to readers how to use the tapes I had discussed, and for which communities and in what settings. 1 had sought her for this task because it was an extension of AIDS activist video work that she (and others) had already been doing, in particular Catherine with her often collaborator Ray Navarro. As an activist community and movement, we thought a lot about seeing and showing our work together and to each other.

TK: This reminds me of a conversation I had this year with artist Sunil Gupta, who has been making pictures, movies, texts, and exhibitions about HIV for over thirty years. For him, his earliest AIDS activist communities were the people he met fighting the proposed budget slashing in the UK in the early 1980s, many of whom were students who took their MA education and poured it into a creative practice in response to AIDS. By the time the AIDS crisis was hitting the UK there were communities of art makers who knew how to galvanize culture in desperate times, and who approached the work using the analytical frameworks of gender, race, and class.

Aj: Oh, Ted. I'm flabbergasted again: Didn't you know this?! Haven't I said and lived this for and with youl? I love you, but think for a minute .... Who do you think I was at that time!? Or my friends? We were twenty=somethings getting our MAs and MFAs and PhDs in New York City. Some of us were already artists or professors or curators. We used this cultural and intellectual capital, one highly influenced by the feminist, postmodern, intersectional, and cultural studies that we were learning, and also began to change it because of AIDS. And that's the birth of Queer Studies!
TK. It is not that I did not know it. I did, eventually. I have come to know that many of the people active in the early days of the crisis came from the civil right movement, women's health activism, and feminism, and the social justice work being done in South Africa and Latin America. But when the history of AIDS media and activism gets told, most often not included is the role that elite institutions and supported artists and activists played. And when the stories do include talk about access, youth, and other privileges in who got to be seen as making change they are most often only told deep within the AIDS response. I think a more nuanced and complex reality of the response to AIDS gets skipped over so the movement never has to discuss privilege in a meaningful way and can escape a conversation around how, even amidst life-saving work, white supremacy, patriarchy, and all the other "isms" did and do still play a defining role.

As a culture we have created an idea that AIDS activism was this pure event that came from the ground up, fueled by passion and dying people's will to live. These are fundamental truths, not to be forgotten or dismissed. And at the same time we have to reconcile with the fact that other factors were also present, of which I at first knew nothing. My first wave of learning about the cultural response to AIDS in the US was one that I pieced together out of digital scraps, the oral tradition, and visits to the library. And nowhere within that self-directed education did I find context: a map of who the people where and how they were able to make change happen beyond a desire for justice.

And the truth is, the limited view I held is represented all around us. Even today, amidst a time of increased social unrest, not a month goes by where there isn't a blog post, article, or radio segment heralding ACT UP as the perfect model for what is needed now. While these are resource-rich pieces of media that speak to real-world activists hardly anywhere in the analysis is there an accounting for what was leveraged for visibility and change. There is not even a hint of a desire to wrestle with the ways in which the loss of black and brown people was largely ignored at the time in exchange for footage of vibrant and virulent white men's bodies, as both victims and heroes. To get this kind of conversation you have to get deep into the weeds.

AJ: I understand what you're saying, but I'm sorry, that place is only "the weeds" if you think that certain ways of fighting, knowing, and representing AIDS are "the flowers"!

TK: I think most people are actually only seeing "the flowers" if they are stopping and smelling anything at all about the epidemic. As a result of the Second Silence and the challenges that have always existed around how the virus is discussed, unless someone understands themselves to be personally impacted, most people's knowledge of HIV is grounded in a mainstream 1996 version of the epidemic, when the life-saving drugs were released and the news media reported that the crisis was all but over. For the most part, people are not aware of the advancements that have been made in the last twenty years, such as less toxic medication being available for people living with HIV; the reduced rates of mother to child transmission world-wide; the role that needle exchanges 
played in saving people's lives; and pharmaceutical interventions for HIVnegative people such as PrEP (pre-exposure prophylaxis, a medical regime that if taken before possible transmission substantially reduces the chance of the virus replicating in a person's body) and PEP (post-exposure prophylaxis, a medical regime that if taken shortly after possible transmission substantially reduces the chances of the virus advancing in a person's bloodstream). Nor are they most likely up to date on HIV Criminalization, the further entrenchment of HIV-related stigma, or the increased disparity that exists around life chances for people living with HIV based on location, income, gender, or race.

And even if someone is living with HIV and has access to trusted sources about the virus, mainstream ideas - those created by and for the flower-sniffing public-can still have a huge impact on one's health, as we see specifically within communities both minoritized and deemed to be high risk. In the US, according to information from the Centers for Disease Control (2015), black women have the fourth highest rate of new HIV diagnoses amid what the CDC calls the "most-affected subpopulations" (with black, white, and hispanic latino men who have sex with men having higher rates, and black heterosexual men, and hispanic/latina and white heterosexual women having lower rates). At the same time, media representations of black women and HIV are mostly unhelpful or nowhere to be found. This is something Tiona McClodden took on in her 2012 short film Bumming Cigarettes, which centers around a black lesbian waiting for the results of an HIV test, which we discussed in an earlier conversation.

So someone can be amidst the weeds and still be informed by the flowers because of the flowers' pungency, something made clear by the Southern AIDS Living Quilt, a YouTube project started in 2008 which gives voice to the impact AIDS has on women living in the southern United States. Explicitly the women in the clips, like you and I, have been alive during the age of AIDS, amid the TV specials, magazine reports, public health posters. Implicitly, HIV is around them. The American South has high rates of new HIV infections, even when the national level is going down. The women, because of the weight of systems they live under, were very much in the weeds when it came to HIV/AIDS. In the clips provided on the Southern AIDS Living Quilt You Tube channel they report hearing nothing about HIV/AIDS before they were diagnosed or hearing only upsetting things about the virus. This, they suggested, was the reason they did not get tested for HIV, nor-wher they knew their status-did they follow up on treatment options. The fear of stigma was greater than their fear for survival. From the videos, Kim, diagnosed in 1994, talks about how she thought she was the first woman in America to have HIV; Pamela shares how she lived ten years knowing her positive status but not seeking care because she was unsure how her family would react; Sigga, a healthcare worker in Kentucky, said she had to tell her doctor that HIV was an issue for women of color in the south.
AJ: Right. And, as you know, this is nothing new to me. You saw clips from the Southern AIDS Living Quilt as part of Compulsive Practice, the short video series I curated with Hugh Ryan and Jean Carlomusto for Visual AIDS Day With (out) Art, 2016. We programmed those videos along with work by nine other "compulsive" videomakers, artists, and activists working from the beginning of the crisis until today with a range of technologies from VHS to iPhones, so that we could show similarities.

TK: And ongoing differences! As you know, I see the release of life-saving drugs in 1996 as a breaking point. After the release of medication there was a split between those for whom the meds meant the end of the crisis and those for whom the meds were life-saving but also just another fraught interaction regarding their survival with the state and society. For poor people, people living with addiction, people of color, women, and almost anyone else living with HIV who was not a middle-class white gay guy with no addiction, the crisis remained, but with less support, representation, and conversation. For resourced gay guys with access to medication, political savvy, and now a taste of triumph, AIDS could be over for them, with new futures possible.

$\mathrm{AJ}$ : And in the space AIDS had once taken up, gay marriage entered.

TK: Yes, but not in the way one might assume. In her book Virtual Equality: The Mainstreaming of Gay and Lesbian Liberation (1995), former National LGBTQ Task Force Director Urvashi Vaid has a chapter called "AIDS and Transformation." She catalogues the ways the AIDS crisis impacted the sexual minority rights movement in the US. AIDS threw open the closet for a generation of lesbian and gay people; increased the size of the mainstream gay press but moved it towards advocacy and away from criticality; and, among other things, rebuilt our minoritized health infrastructures. Before AIDS, of course, there was a healthy women's health movement and an increasing awareness around health for gay men, specifically around sexuality. As Vaid suggested in her book, AIDS brought the expertise gained from these related yet different health movements together in a very urgent manner, so much so that structural issues were not addressed. Specifically, Vaid argued that the response to AIDS from lesbian and gay communities invested in mainstreaming for clear short-term gains, with the hope of long-term equality, giving little thought to what this would mean to minoritized communities already underserved. In Virtual Equality, Vaid (1995) wrote: "In place of liberation the AIDS movement substituted nondiscrimination; instead of building a movement it built agencies and bureaucracies; instead of placing its political faith in training and organizing gay and lesbian people and our allies into an electoral coalition, it placed its faith in friends in high places" (p. 91).

Af: I think it is safe to say that we all bring our context with us. Women and AIDS (1987), a video I made with Jean Carlomusto at GMHC, emerged from and represented a highly organized local scene of feminist activists, social workers, government employees, artists, and intellectuals who were developing analysis about oppression, power, gender, race, class, and sexuality alongside an AIDS 
politics. We were sharing this together and learning from women around the US and the world! These sets of linked ideas, now called "intersectionality," were under development, analysis, and retooling at that time, and before, just as they are now!

TK: Right, and I think this is what Vaid was getting at. Women and AIDS speaks to the problematic dynamics of the time, propels life-saving information forward, and tackles the systemic issues that led to and exacerbated the crisis of AIDS. It is a video positioning HIV as an issue of systemic inequality for poor and minoritized populations. But this is not the legacy of AIDS activism currently playing out on screens and gallery walls. Instead, what we are seeing are representations of AIDS as primarily an interruption of gay rights successes that can be understood as within reach in the 1970 s, maybe best exemplified by the rise of gay men within the Democratic Party. This is literally where Randy Shilts, in And The Band Played On (1987), begins. Marriage then becomes the talisman of sorts of what was lost, and now reclaimed. It is positioned as an assuagement to AIDS. Both Larry Kramer: In Love \& Anger (Carlomusto, 2015) and Back on Board: Greg Louganis (Furjanic, 2014)-portraits within the canon of the AIDS Crisis Revisitation of very different men — end with gay marriage, a third act in which the AIDS tragedy in the middle is overcome. Similarly, Dr. Perry N. Halkitis' book The AIDS Generation: Stories of Survival and Resilience (2014) is on one hand a much-needed look into the role that addiction, trauma, and HIV play in the lives of gay men in the US, but on the other is also a primarily white-washed story of AIDS history rooted in gay exceptionalism in which the story of gay men and HIV is posited as the story of AIDS in the US, erasing black people, as well as others from the many communities impacted by the epidemic.

There is a shared logic between what allowed for gay marriage to emerge as the gay issue after 1996 and the narrowness of the AIDS Crisis Revisitation we are seeing now. Both omit the intersectional approaches to AIDS activism and the reality of who is living with HIV that you, Sunil, and others brought to the work and which continues to this day.

\section{Part 2}

\section{Nothing new: AIDS films and the struggle for diversity}

TK: Just recently, when you looked through your research files for AIDS TV, you found and then shared with me a report called Retooling for Diversity, by Renee Tajima and Ernesto de la Vega (AIDSFilms, 1992). It was funded by the Rockefeller Foundation to explore the way an AIDS-specific production company called AIDS Films decided to move from being an organization with all-white leadership to one that attempted to be more diverse in both its production processes and crews, and to the communities it represented and to which it reached out. I think by looking at this document we make space for us to make sense of the frustrations and sadness, past, present, and maybe future. AIDS Film achieved success by straddling mainstream and alternative worlds with their 1987 film AIDS: Changing the Rules (Getchell et al., 1987), a twenty-six-minute educational film hosted by presidential son Ron Reagan and model Beverly Johnson. It was presenting possibly uncomfortable information in a comfortable way. It was broadcast on PBS, had very wide distribution (for an educational film), and was eventually translated into Spanish.

AJ: AIDS Film was an important contributor to the AIDS video scene and they were very well funded (respective to other media projects). They could make a particular register of work. Their first major funding came in the amount of $\$ 106,000$ from a benefit. There was almost no one else working with that kind of budget! They also received money from the NYC Community Trust, the Reverson Foundation, and eventually the Ford Foundation. This is an example of the kinds of resources accessible early on in the crisis to gay white men who used it effectively and quickly when there was no government or even non-governmental response to AIDS. Efforts for response and well-being were cobbled together from personal resources and connections. Later, as other communities knew that they would need to care for themselves as well, other funding efforts were engaged. For example, my activist video and doctoral research project We Care: $A$ Video for Care Providers of People Affected by AIDS (The Women's AIDS Video Enterprise, 1990) was funded primarily by the New York State Council for the Humanities (interesting resonance with our world today, given the current uncertainty of ongoing funding for the NEH and the NEA). It felt very well-funded to me, with a $\$ 25,000$ grant that went primarily to run the video-support group at BATF from which the tape was made. The money was used to support the women who were making it, not for a more traditional high-end look and practice.

TK: From the report I learned that, after the success of their first film, the producers of AIDS Films went looking for another project, and they found that things were changing. In between starting the company and getting their first film out the world of AIDS media and activism was expanding. By their own admission, AIDS Films had a very narrow focus to start with. According to the report, John Hoffman, a founder of AIDS Films, said "We thought white gay men were the epidemic." By 1987 this was no longer an acceptable way" of thinking about the epidemic in many, but of course not all, activist circles. AIDS Films wanted to catch up. Not only was HIV not understood to be just a gay disease, it was also being made clear within activist communities that it was and had been impacting black communities and communities of color all along. The founders began the process of bringing in "diverse" voices, and the report suggests that they struggled and fumbled at every step of the way. They brought in leadership from communities of color, who had a wealth of experience from within the AIDS community and the many vantages of AIDS response. The report testified that when AIDS Films tried to do this, the new members did not feel welcome. The report explained how even the invitation 
to join AIDS Films felt like a test where they had to prove themselves, and how at every meeting they often felt unheard. The report argued that the early staff of AIDS Films did not have the skills to appreciate the rich but differently focused AIDS and media knowledge of the new members they recruited. Tajima and de la Vega (1992) wrote, "People of color have universal skills to bring to a board--artistic or scholarly expertise, fundraising, board leadership, financial management, advocacy, legal expertise, arts administration-that can exceed those of existing members" (p. 11). The people in charge at AIDS Films tokenized the new members, seeing them not as contributors who could have an impact and therefore create change within the organization but rather as "diverse" faces to have around the table that mostly made things harder.

Af: What I like about the report is less that AIDS Films is blamed for their missteps per se and more that it aims to name the missteps and assumptions that surrounded them. Seeing the subtle hold of racism and sexism within our most well-meaning communities gives us all useful clarity.

TK: Leaming that an AIDS media production company attempted to address the white supremacy that they were operating under, with mixed results for the people involved, is important to consider. In the same years that the new members joined the committee, AIDS Films also produced three short films: Seriously Fresh (Life, 1989), about and for black male youth; and Are You with Me? (Barnette, 1989) and Vida (Portillo, 1989), short narratives set in the black and latinx communities that focused upon interactions between women and children. Watching Are You With Me? with you was a revelation. The audience enters the film learning about the funeral of a young black woman who recently died of AIDS, and the impact her death is having on those around her. The film begins by telling the story of another young black woman, suggesting that she is the most at risk. But, as the film progresses, it is clear that this young woman already has the information and fortitude to get what she needs to survive. Her risk is mitigated by information, esteem, and support. Instead, we see that it is her mother, dating later in life, who is at risk because she does not see HIV as a disease relevant to adult women. It is a subtle and kind story about motherdaughter love that centers black female desire across and between generations and the structures that impede it.

AJ: Yes, a hard part of the work is that we have to help people to understand what they are watching-its contexts of funding, production, and reception-to ensure they can acknowledge the unique and local power of what is on view.

TK: I think a lot of the work we discuss gets lost in part because it doesn't fit into the Gay rights narrative asserted into the story of AIDS in the USA. I think a reason a film like Are You With $M e$ ? does not get remembered is that white gatekeepers can't recognize the life-saving labour being performed in the film. If someone's metric for change is metered in visuals of direct action, it might be hard to see holding space and relationship building, present in Are You With $M e$ ? Nor may they even understand these as HIV prevention methods.
Aj: That less-valued and usually invisible work is about self and community care when the artist or artists are speaking from a position where none of this can be taken for granted, where none of this-voice, resources, health, education, self-love-are a given. Which gets us back to where we started: Villanelle. In the video a male voice explains, "to be intimate and personal, you have all this political weight pressed upon that."

TK: Hyatt's film ends with a voice wondering: if maybe an impact of HIV/AIDS is that it finally gave a name, and a tangibility of sorts, to "the political weight" that has long greeted queer people at the moment of possible intimacy. This ending serves as a reminder that media making can be an act of intimacy: a telegram between the past, present, and future. As much as media can help ensure that progress is documented, we still need each other, be it to hit record, or help us re-engage ourselves with our own memories and archives.

AJ: Which brings up the logical question: what must be done to eliminate further erasures of histories caused by inclusions and erosions resulting from flawed systems created and maintained by people who are not always willing, able, or equipped to consider the needs of those already underserved?

TK: Bringing an obvious urgency to this question of course is Trump, and the quality of life for poor people, sick people, and other minoritized people living under his administration. This refers not only to healthcare, education, and the toll that a law-and-order state has on people, but also to the cuts in funding surely to come for the arts, culture, and libraries.

AJ: We now see a generation of scholars, artists, and others working online and off to think through what a digital future can mean for activism and for communities whose stories and histories have long gone either untold or unstored.

TK: Interesting to consider, when thinking about a digital future, is the role of technology. Currently, one tape at a time, you and people you work with are digitalizing your AIDS video archive, otherwise that work would be trapped on your office shelf. Documentation from the past is only as good as available technology, and willing and informed people. Hyatt's film is a wonder for me because as much as it is a film-that is to say, a product made possible by technology-it is also an artifact of much longer-lasting practices: person to person communication, the oral tradition, storytelling, the art of asking questions. Just like marriage does not mean queer equality for all, media made does not ensure media viewed.

AJ: In light of everything else that the ongoing response to HIV/AIDS has to share with us, this is a tiny, but mighty, lesson. We have to resist the urge to think the work is done once the media is made, circulated once, or liked on some social network; we need be vigilant in telling our stories even if we think no one will listen or understand; and we can be generous in our listening, learning to ask questions around what we don't know we don't know. 


\section{Film suggestions}

Busbee, S., Jawitz, M., Ward S., Basinger, J. (1989). He Lefi Me His Strength. USA: Downtown Community TV.

Carlomusto, J. (Dir.) (2015). Larry Kramer: In Love \& Anger. USA: HBO Documentary Films.

France, D. (Dir.) (2012). How to Survive a Plague. USA: http://surviveaplague.com/

Friedman, P., Joslin, T. (Dir.) (1993). Silverlake Life. USA: docurama films.

Furjanic, C. (Dir.) (2014). Back on Board: Greg Louganis. USA: HBO Documentary Films.

Hubbard, J. (Dir.) (2012). United in Anger: A History of ACT UP. USA: www.unitedinanger. com/

Hyatt, H. (Dir.) (2015). Villanelle. USA: project.villanelle@gmail.com

McClodden, T. (Dir.) (2012). Bumming Cigarettes. USA: Harriet's Gun Media.

Rappaport, M. (Dir.) (1992). Rock Hudson's Home Movies. USA: YouTube: www.youtube. $\mathrm{com} / \mathrm{watch}$ ? $\mathrm{v}=\mathrm{Ox} 86 \mathrm{QDhO} 1 \mathrm{ZY}$

Riggs, M. (Dir.) (1992). Non, Je Ne Regrette Rien (No Regret). USA: Video Data Bank.

Saalfield, C., Leonard, Z. (Dir.) (1990). Keep Your Laws off $m y$ Body. USA: Audin Pictures, www.aubinpictures.com/films.htm

WAVE. (Dir.) (1995). We Care: A Video for Care Providers of People Affected by AIDS. USA: Alexandra Juhasz.

Wein, D. (Dir.) (2008). Sex Positive. USA: Roco Films.

Winter, S. (Dir.) (1996). Chocolate Babies. USA: Vimeo: https://vimeo.com/62632619

\section{Resources for teaching AIDS video through a critical lens}

Cheng, J. (2016). How to Survive: AIDS and Its Afterlives in Popular Media, WSQ: Women's Studies Quarteriy, 44(1-2), 73-99.

Geary, A. (2014). Antiblack Racism and the AIDS Epidemic. New York: Palgrave Macmillan. Hilderbrand, L. (2006). Retroactivism, GLQ, 12(2), 303-317.

Juhasz, A. (1994, 1995). So Many Alternatives: the Alternative AIDS Video Movement. CINEASTE magazine, 20(4) (1994); 21(1-2) (1995).

Juhasz, A. (1995). AIDS TV: Identity, Community, and Altemative Video. Durham, NC: Duke University Press.

Juhasz, A., Kerr, T. (2014). Home Video Returns: Media Ecologies of the Past of HIV/ AIDS. Retrieved from www cineaste.com/summer2014/home-video-returns-mediaecologies-of-the-past-of-hiv-aids/

Juhasz, A., Kerr, T. (2014). AIDS Reruns: Becoming 'Normal'? A Conversation on 'The Normal Heart' and the Media Ecology of HIV/AIDS. August 18, 2014. Retrieved from www.indiewire.com/2014/08/aids-reruns-becoming-normal-a-conversation-on-thenormal-heart-and-the-media-ecology-of-hivaids-216116/

Juhasz, A., Kerr, T. (2015). Encounters: Media Fields Collective Conference at UCSB, Santa Barbara, CA.

Juhasz, A., Kerr, T. (2017). After Marriage: The Future of LGBTQ Politics and Scholarship, New York.

Juhasz, A., Kerr, T. (2017). Stacked on Her Office Shelf: Stewardship and AIDS Archives. January 13, 2017. Retrieved from www.centerforthehumanities.org/blog/stacked-onher-office-shelf-stewardship-and-aids-archives

Kerr, T. (2013). I made mourning productive, collective, and interactive through video production. February 5, 2013. Retrieved from www.visualaids.org/blog/detail/i-mademy-mourning-productive-collective-and-interactive-through-video-prod
Kerr, T. (2013). When ACT UP is remembered ... other places, people, and forms of AIDS activism are disremembered, February 17, 2013. Retrieved from www.visualaids. org $/ \mathrm{blog} / \mathrm{detail} / 7414$

Palmer,T. (2015). Under the Rainbow. The New Inquiry. July 28, 2015. Retrieved from https://thenewinquiry.com/under-the-rainbow/

Ryan, H. (2013). How to Whitewash a Plague. The New York Times. August 3, 2013. Retrieved from: www.nytimes.com/2013/08/04/opinion/sunday/how-to-whitewasha-plague.html

\section{Examples of Trump era activist media that references}

AIDS activism

Goldberg, M. (2016). Lessons for Fight a Demagogue, From the People Who Survived a Plague. Slate. December 16, 2016. Retrieved from: www.slate.com/articles/news_and politics/politics/2016/12/how_the_aids_movement_has_given_birth_to_the_trump_ resistance.html

Kessler, P. (2017). Lessons for Anti-Trump Activists from ACT UP. Medium. February 1 , 2017. Retrieved from: https://medium.com/@PippiKessler/lessons-for-anti-trumpactivists-from-act-up-796374fb96c

Murphy, T. (2016). AIDS Activist Peter Staley is Ready to Get Arrested Fighting Trump. Towleroad. December 15, 2016. Retrieved from: www.towleroad.com/2016/12/peterstaley-trump/

Westervelt, E. (2017). ACT UP at 30: Reinvigorated for Trump Fight. April 17, 2017 Retrieved from: www.npr.org/2017/04/17/522726303/act-up-at-30-reinvigoratedfor-trump-fight

\section{References}

Brooklyn AIDS Task Force. (1988). Durand, Y. (1988). Mildred Pearson: When You Love a Person. USA: unavailable.

Centers for Disease Control. (2015). HIV Among African Americans. Retrieved from: www.cdc.gov/hiv/group/racialethnic/africanamericans/

Getchell, F., Hoffman, J., Tross, S. (1987). AIDS: Changing the Rules. USA: AIDSFilms.

Halkitis, P. (2014). The AIDS Generation: Stories of Survival and Resilience. London: Oxford University Press.

Juhasz, A., Carlomusto, J. (1987). Women and AIDS. USA: GMHC.

Life, R. (1989) Seriously Fresh. USA: AIDS Film.

Neema Barnette, M. (1989). Are You With Me? USA. AIDS Films.

Portillo, L. (1989). Vida. USA: AIDS Films.

Shilts, R. (1987). And the Band Played On: Politics, People and the AIDS Epidemic. New York, NY: St. Martin's Press.

Southern AIDS Living Quilt. (2008). Southern AIDS Living Quilt. USA: www.youtube. com/user/SouchernAIDSQuilt

Tajima, R., de la Vega, E. (1992). Retooling for Diversity. USA: AIDSFilms.

Vaid, U. (1995). Virtual Equality: The Mainstreaming of Gay and Lesbian Liberation. New York, NY: Penguin/Random House.

The Women's AIDS Video Enterprise. (1990). We Care: A Video for Care Providers of People Affected by AIDS. USA: Alexandra Juhasz. 